\title{
Implementation of ISO 14000 in Luggage Manufacturing Industry: A Case Study
}

\author{
S. B. Jaju \\ G. H. Raisoni College of Engineering, \\ Department of Mechanical Engineering, Nagpur \\ India
}

\section{Introduction}

Definitions of EMS as provided by three separate documents on environmental management systems are as given below

ISO 14001: "the organizational structure, responsibilities, practices, procedures, processes and resources for implementing and maintaining environmental management"

BS 7750: "the organizational structure, responsibilities, procedures, processes and resources for implementing environmental management"

Eco-Management and Audit Scheme (EMAS): "that part of the overall management system which includes the organizational structure, responsibilities, practices, procedures, processes and resources for determining and implementing the environmental policy"

\section{Development of the ISO 14000 series}

The ISO 14000 family includes the ISO 14001 standard, which represents the set of standards used by various types of organizations for designing and implementing an effective environmental management system. The major objective of the ISO 14000 series of norms is "to promote more effective and efficient environmental management in organizations and to provide useful and usable tools - ones that are cost effective, system-based, and flexible and reflect the best organizations and the best organizational practices available for gathering, interpreting and communicating environmentally relevant information".

Unlike previous environmental regulations, which began with command and control approaches, later replaced with ones based on market mechanisms, ISO 14000 was based on a voluntary approach to environmental regulation. The series includes the ISO 14001 standard, which provides guidelines for the establishment or improvement of an EMS. The standard shares many common traits with its predecessor ISO 9000, the international standard of quality management, which served as a model for its internal structure and both can be implemented side by side. As with ISO 9000, ISO 14000 acts both as an internal management tool and as a way of demonstrating a company's environmental commitment to its customers and clients.

Prior to the development of the ISO 14000 series, organizations voluntarily constructed their own EMS systems, but this made comparisons of environmental effects between companies difficult and therefore the universal ISO 14000 series was developed. An EMS is defined by 
ISO as: "part of the overall management system, that includes organisational structure, planning activities, responsibilities, practices, procedures, processes and resources for developing, implementing, achieving and maintaining the environmental policy'.

\section{Driving forces}

\section{Environmental concerns}

For a number of years preceding the introduction of a formal EMS, there was a genuine concern about its various environmental impacts. Some typical examples of impacts are:

- $\quad$ energy and resource usage (electricity, gas, water)

- $\quad$ raw material usage (paper, plates, inks, packaging, chemicals, film)

- general waste (domestic)

- recyclable waste (paper, timber, aluminum, silver, plastics)

- hazardous waste (chemical wastes, liquid effluent, air emissions)

- $\quad$ nuisances (noise, litter, dust, odors)

- contracted activities (transport, subcontracted printing work)

- $\quad$ product end use and disposal

Legal obligations

Over recent years, there have been considerable changes in environmental legislation. Every organisation wants to address its legal obligations, such as compliance with effluent discharge license parameters, or local authority planning requirements. Integrated Pollution Control licensing, for instance, will eventually oblige most industries to comply with stricter industry guidelines on pollution control, with the threat of heavy financial penalties resulting from non-compliance.

\section{Customer pressure}

Lot of pressure is from customer end that is the basic aim of any organisation. Ultimately customer should have faith in the industry that the said industry is having compliance for environmental parameters.

\section{Basic principles and methodology}

The fundamental principle and overall goal of the ISO 14001 standard, is the concept of continual improvement. ISO 14001 is based on the Plan-Do-Check-Act methodology, grouped into five phases that relate to Plan-Do-Check-Act; Environmental Policy, Planning, Implementation \& Operation, Checking \& Corrective Action and lastly Management Review.

\section{Plan - establish objectives and processes required}

Prior to implementing ISO 14001, an initial review or gap analysis of the organisation's processes and products is recommended, to assist in identifying all elements of the current operation and if possible future operations, that may interact with the environment, termed environmental aspects. Environmental aspects can include both direct, such as those used during manufacturing and indirect, such as raw materials (Martin 1998). This review assists the organisation in establishing their environmental objectives, goals and targets, which should ideally be measurable; helps with the development of control and management 
procedures and processes and serves to highlight any relevant legal requirements, which can then be built into the policy.

\section{Do - implement the processes}

During this stage the organisation identifies the resources required and works out those members of the organisation responsible for the EMS' implementation and control. This includes documentation of all procedures and processes; including operational and documentation control, the establishment of emergency procedures and responses, and the education of employees, to ensure they can competently implement the necessary processes and record results. Communication and participation across all levels of the organisation, especially top management is a vital part of the implementation phase, with the effectiveness of the EMS being dependant on active involvement from all employees.

\section{Check - measure and monitor the processes and report results}

During the check stage, performance is monitored and periodically measured to ensure that the organisation's environmental targets and objectives are being met (Martin 1998). In addition, internal audits are regularly conducted to ascertain whether the EMS itself is being implemented properly and whether the processes and procedures are being adequately maintained and monitored.

\section{Act - take action to improve performance of EMS based on results}

After the checking stage, a regular planned management review is conducted to ensure that the objectives of the EMS are being met, the extent to which they are being met, that communications are being appropriately managed and to evaluate changing circumstances, such as legal requirements, in order to make recommendations for further improvement of the system. These recommendations are then fed back into the planning stage to be implemented into the EMS moving forward.

\section{Role of EMS}

1. An assessment of the existing practices and situation of an organization.

2. A register of all environmental effects associated with the company's activities, established through an initial environmental review.

3. A list of all legislation relevant and applicable to the environmental aspects of the activities, products and services of the organization.

4. Development of a corporate environmental policy and environmental management plan

5. The setting of environmental performance objectives and targets for both current and future activities.

6. Development of environmental performance evaluation procedures.

7. Establishment of an effective environmental training program for all employees within the organization, which will raise awareness, enhance skills for dealing with environmental issues and stress compliance with relevant legislation.

8. Implementation of a system, which reliably manages the performance of the organization, for both current and future activities.

9. Documentation of the system communicated to all employees and distributed to all interested parties, especially to the public.

10. Establishment of non-conformance and corrective and preventive action procedures. 
11. Regular checking, reviewing and auditing of company practices and management commitment to reflect changing conditions with a focus on continual improvement.

\section{Benefits of EMS implementation}

\subsection{Natural}

1. Clean Air, Water, Soil.

2. Prevention and/or significant reduction of pollution and waste Generation.

3. Improved health and safety of interested parties.

4. Reduction in the use of non-renewable resources.

5. Improved conservation and efficient use of natural resources.

\subsection{Corporate}

1. Reduced financial costs through reduction in consumption of resources and through waste minimization.

2. Reduction and/or avoidance of potential emergency situations.

3. Avoidance of incidence of non-compliance with legislation and reduction in fines and cleanup costs.

4. Reduction in the cost of gaining capital, financial backing, insurance and valuation by becoming an "environmentally friendly" organization.

5. Improved marketing advantage as a "green" operation.

6. Increased staff morale and occupational safety and health standards.

7. Improved customer, client and community relations.

8. Increased documentation, communication and feedback of environmental policies and initiatives.

\section{Major requirements of ISO 14000}

Following are some of the requirements of ISO 14000:

1. Environmental protection as one of the highest corporate priorities with clear assignment of responsibilities and accountabilities to all employees.

2. Compliance with all environmental laws and regulations applicable to the company's activities, products and services.

3. Ongoing communications on environmental commitment and performance with all shareholders.

4. Strategic planning that sets forth environmental performance objectives and targets, implemented through a disciplined management process.

5. Periodic performance measurement (as well as systems audits and management reviews) to achieve continual improvement wherever possible.

6. Full integration with health and safety, quality, finance, business planning and other essential management processes.

7. Focus on EMS and looks for attributes that would sustain sound environmental decision making and performance.

8. Top management commitment.

9. Third-party registration, through ISO 14001, or self-declaration for companies that meet the ISO 14000 standards. ISO 14001 includes discrete elements of environmental aspects, legal requirements, objectives and targets, environmental management program, communications, and emergency preparedness and response. 


\section{Stage by stage implementation of ISO 14001}

First stage: commitment and policy

i. Environmental policy

\section{Second stage: Planning}

i. Environmental aspects

ii. Legal and other requirements

iii. Objectives and targets

iv. Environmental management program

Third stage: Implementation

i. Structure and responsibility

ii. Training, awareness and competence

iii. Communication

iv. Environmental documentation

v. Document control

Fourth stage: Operational control measurement and evaluation

i. Monitoring and measurement

ii. Non-conformance and corrective and preventive action

iii. Records

iv. Environmental management system audit

Fifth stage: Review and improvement

i. Management review

\section{Benefits of developing ISO 14000 series}

1. Having a single, global set of environmental management system guidance standards.

2. The development of a common, global approach to voluntary and self-directed environmental management.

3. Enhancement of the ability to measure levels of sustainability and environmental performance through auditing methods.

4. Harmonization of non-uniform standards for a range of environmental impact issues.

\section{Implelementation OF ISO 14000 in luggage manufacturing industry:}

The study is done for Canteen and Tools and Mould repairing.

CANTEEN: Firstly the various input to canteen are identified viz. Vegetables, spices, oil, food grains, water, LPG gas, Electricity. Output of the canteen is Food products.

The various effects of the canteen on the environment as a whole are identified

1. Used water discharged to drainage.

2. Fire in L. P. G. (Emergency).

3. Solid waste non biodegradable (Carboys, drums, containers, empty milk bags).

4. Solid waste biodegradable (spent food and vegetables).

5. Fume generation.

6. Heat loss to atmosphere. 
7. Noise generation.

The complete canteen as process showing input and output as well its effects on environment are tabulated in aspect register as shown in Table I.

Each aspect is studied carefully for the following category of aspects:

1. Normal aspects: Effects of aspects are negligible.

2. Abnormal Aspects: Severe effect on environment.

3. Emergency Aspects: Nature of Aspect is emergency. Emergency prepared plan has to be there. Proper training to be given to the people for handling the emergency situations. They should be equipped with safety devices to tackle the emergency. For example: Suppose if there is a fire hazard. Whether the fire fighting equipment is there or not. If it is there then whether the people are trained to operate it and so on.

Emergency preparedness plan for every department, which will consist of the following few points:

1. Fire equipments are available or not that too in proper place.

2. Are the people trained to handle the situations?

3. Security people should be trained.

4. First aid training is to be given to all.

5. Fire equipments layout, number of fire equipments, is to be planned.

6. Emergency siren should start immediately after the fire.

7. All people should assemble at one place.

Factor rating is applied to each aspect depending on various factors. The various ratings used are

\section{A: Occurrence}

\begin{tabular}{|l|c|}
\hline Continuous (8hours \& above)/day & 5 \\
\hline Less than 8 hours/day & 4 \\
\hline Less than 8 hours/week & 3 \\
\hline Less than 8 hours/month & 2 \\
\hline Less than 8 hours/year & 1 \\
\hline
\end{tabular}

\section{C: Significance of Impact}

\begin{tabular}{|l|c|}
\hline $\begin{array}{l}\text { Causing death to human being on site/ offsite, damage } \\
\text { to flora fauna, air, water, land (offsite). }\end{array}$ & 5 \\
\hline $\begin{array}{l}\text { Damage to flora fauna, air, water, land or } \\
\text { hospitilisation to human being on site. }\end{array}$ & 4 \\
\hline $\begin{array}{l}\text { Damage to flora fauna, air, water, land or first aid to } \\
\text { human being on shop }\end{array}$ & 3 \\
\hline $\begin{array}{l}\text { Damage to flora fauna, air, water, land and or first aid } \\
\text { to human being on shop }\end{array}$ & 2 \\
\hline Negligible impact & 1 \\
\hline
\end{tabular}




\section{D: Controls}

\begin{tabular}{|l|l|}
\hline Controls absent & 5 \\
\hline Controls present & 4 \\
\hline Controls present but needs human intervention & 3 \\
\hline Controls present no human intervention & 2 \\
\hline Closed loop control & 1 \\
\hline
\end{tabular}

\section{E: Frequency of Detection}

\begin{tabular}{|l|l|}
\hline Once in a year \& above & 5 \\
\hline Once in six months & 4 \\
\hline Once in one to three months & 3 \\
\hline Once in a week & 2 \\
\hline Once in a day & 1 \\
\hline
\end{tabular}

\section{F: Category of waste}

\begin{tabular}{|l|c|}
\hline Hazardous waste & 5 \\
\hline Non-hazardous waste (High) & 4 \\
\hline Non-hazardous waste (Low) & 3 \\
\hline $\begin{array}{l}100 \% \text { recycled in house or recycled from outside party } \\
\text { for inside use }\end{array}$ & 2 \\
\hline Negligible waste generation & 1 \\
\hline
\end{tabular}

The factor rating of impacts for each aspect is shown in Table II.

After categorisation of aspects, their impact has to be ascertained. Then whether they can be measured or not. If measured, what is the present status? Then the frequency of occurrence is to be known. Further what is the treatment given to nullify the bad effects of aspects on environment? All these analysis is depicted in Table III.

After rating and critical analysis of each aspect one should have the action plan for the aspect, which is affecting severely on environment. Meetings should be conducted to take reviews on the improvement after the implementation of action plan. The improved status to be maintained and periodic review are done to ascertain.

In the similar way study is carried out for process of TOOL AND MOULD REPAIR and the reports are shown in Table IV, V and VI.

\section{Conclusion}

With the implementation of EMS, communications concerning environmental practices were streamlined. It was possible to identify areas where utility savings existed. EMS defined roles and responsibilities towards each aspect of the process and their impacts on the environment. A systematic approach is understood to handle environmental issues in place and the overall plant cost savings coming from tracking resources and accounting for them. The EMS also provides the more intangible benefit of employee taking pride of working in the plant that is a good environmental neighbour. 
Table No. I

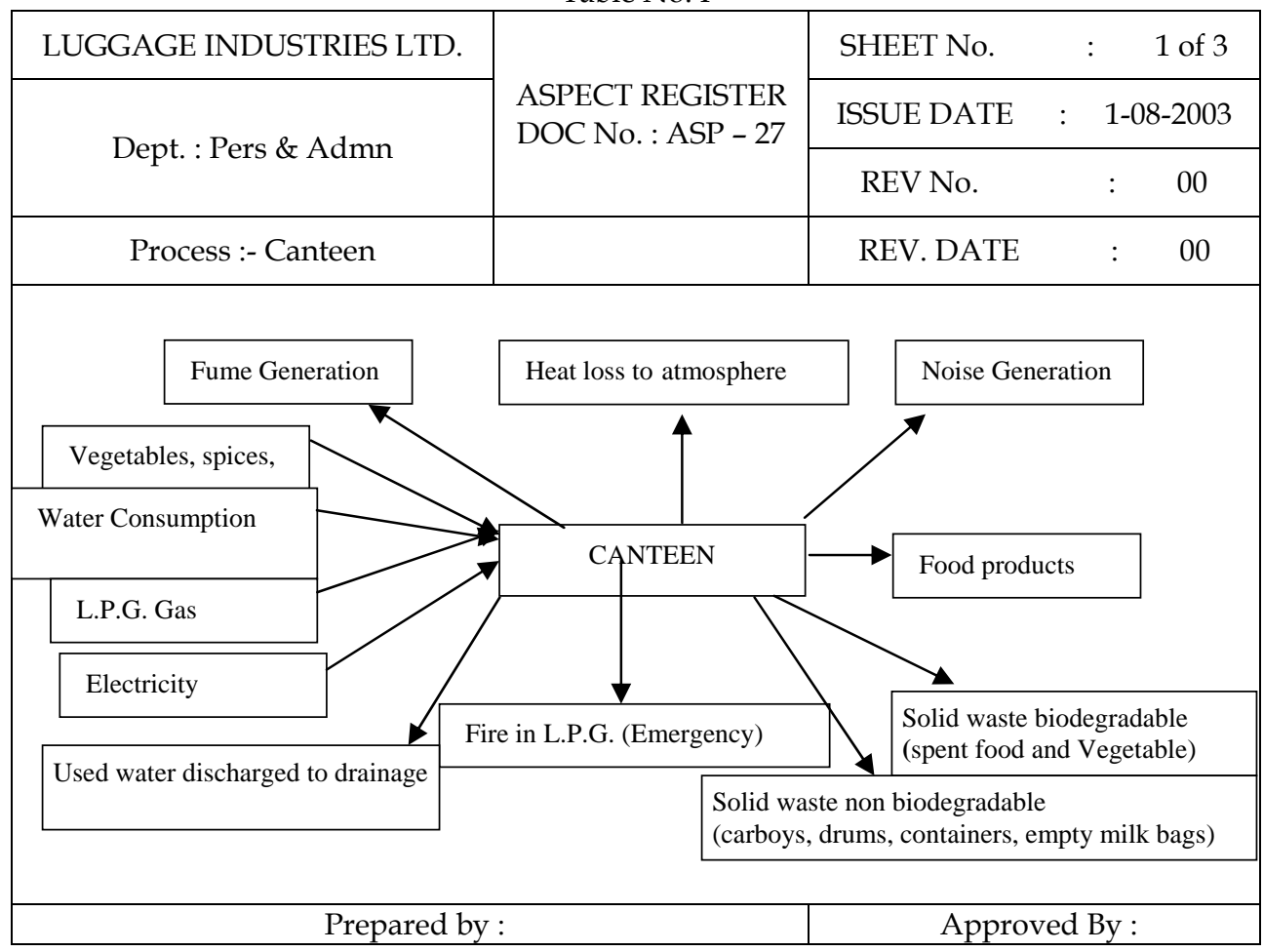


Table No. II

\begin{tabular}{|c|c|c|c|c|c|c|c|c|c|}
\hline \multirow{3}{*}{\multicolumn{2}{|c|}{$\begin{array}{c}\text { LUGGAGE } \\
\text { INDUSTRIES LTD. } \\
\text { Dept. : Pers \& Admn }\end{array}$}} & \multirow{4}{*}{\multicolumn{4}{|c|}{$\begin{array}{l}\text { ASPECT REGISTER } \\
\text { DOC No. : ASP - } 27\end{array}$}} & \multicolumn{3}{|c|}{ SHEET No. } & \multirow{2}{*}{$\begin{array}{c}3 \text { of } 3 \\
1-08-2003 \\
\end{array}$} \\
\hline & & & & & & \multicolumn{3}{|c|}{ ISSUE DATE } & \\
\hline & & & & & & \multirow{2}{*}{\multicolumn{3}{|c|}{$\begin{array}{l}\text { REV No. } \\
\text { REV. DATE }\end{array}$}} & 00 \\
\hline \multicolumn{2}{|c|}{ Process :- Canteen } & & & & & & & & 00 \\
\hline \multirow{2}{*}{$\begin{array}{l}\text { Sr. } \\
\text { No. }\end{array}$} & \multirow{2}{*}{ ASPECT } & \multicolumn{6}{|c|}{ FACTOR RATING } & \multirow{2}{*}{$\begin{array}{c}\text { TOTAL } \\
\text { RATING }\end{array}$} & \multirow{2}{*}{$\begin{array}{c}\text { IS IT } \\
\text { SIGNIFICANT }\end{array}$} \\
\hline & & A & $\mathrm{B}$ & $\mathrm{C}$ & $\mathrm{D}$ & $E$ & $\mathrm{~F}$ & & \\
\hline \multicolumn{10}{|c|}{ NORMAL ASPECTS } \\
\hline 01 & $\begin{array}{c}\text { Fume } \\
\text { Generation }\end{array}$ & 5 & 1 & 1 & 2 & 5 & 1 & 15 & No \\
\hline 02 & Heat loss & 5 & 1 & 1 & 2 & 5 & 1 & 15 & No \\
\hline 03 & $\begin{array}{c}\text { Noise } \\
\text { generation }\end{array}$ & \multicolumn{7}{|c|}{-- -- -- -- -- S T A T U T O R Y -- -- -- -- -- } & YES \\
\hline 04 & $\begin{array}{c}\text { Discharge of } \\
\text { used water }\end{array}$ & 5 & 3 & 1 & 3 & 3 & 3 & 18 & YES \\
\hline 05 & \begin{tabular}{|c|} 
Solid waste \\
biodegradable \\
spent food \\
vegetable \\
\end{tabular} & 5 & 3 & 1 & 3 & 3 & 3 & 18 & YES \\
\hline 06 & $\begin{array}{c}\text { Solid waste } \\
\text { non } \\
\text { biodegradable } \\
\text { corboys drums } \\
\text { containers etc. }\end{array}$ & 2 & 1 & 1 & 3 & 3 & 3 & 13 & No \\
\hline \multicolumn{10}{|c|}{ ABNORMAL ASPECTS } \\
\hline 07 & Nil & Nil & Nil & Nil & Nil & Nil & Nil & Nil & No \\
\hline \multicolumn{10}{|c|}{ EMERGENCY ASPECTS } \\
\hline 08 & $\begin{array}{l}\text { Fire in L.P.G. } \\
\text { Storage area }\end{array}$ & & & & & & & & YES \\
\hline \multicolumn{6}{|c|}{ Prepared by : } & \multicolumn{3}{|c|}{ Approved By : } & \\
\hline
\end{tabular}


Table No. III

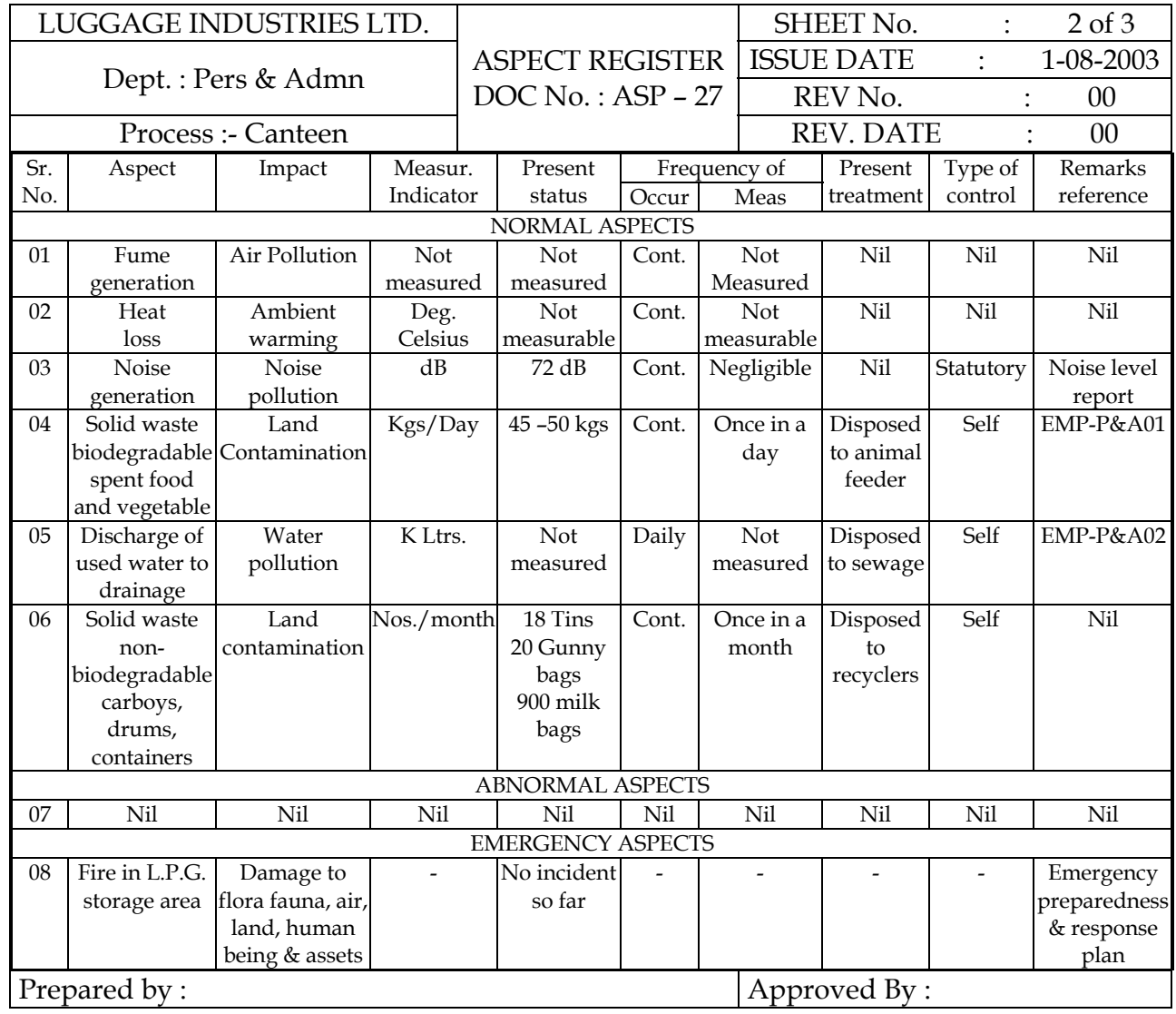


Table No. IV

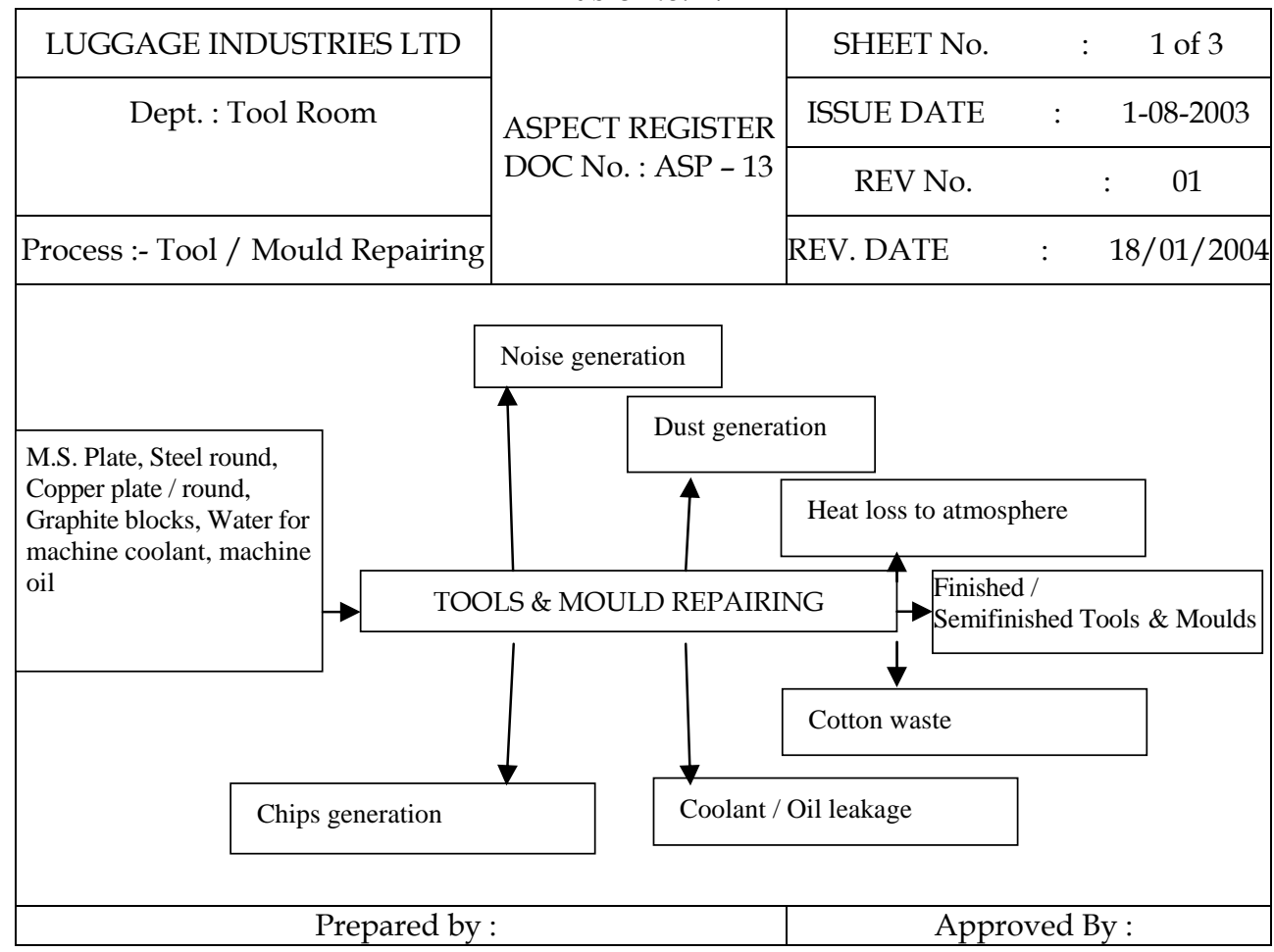


Table No. V

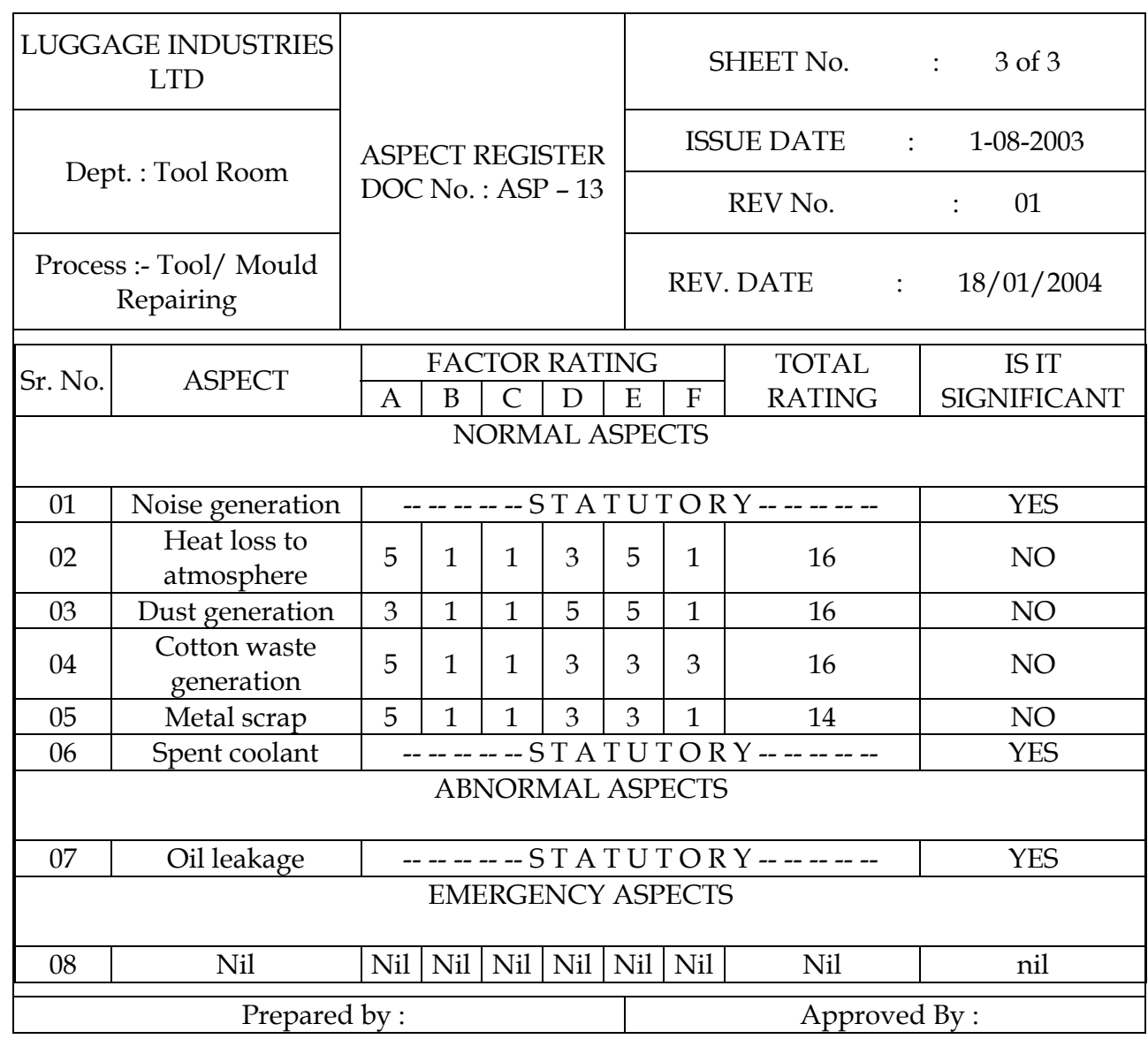


Table No. VI

\begin{tabular}{|c|c|c|c|c|c|c|c|c|c|c|}
\hline \multicolumn{4}{|c|}{ LUGGAGE INDUSTRIES LTD. } & \multirow{4}{*}{\multicolumn{3}{|c|}{$\begin{array}{l}\text { ASPECT REGISTER } \\
\text { DOC No. : ASP - } 13\end{array}$}} & \multirow{2}{*}{\multicolumn{2}{|c|}{$\begin{array}{l}\text { SHEET No. } \\
\text { ISSUE DATE }\end{array}$}} & : & 2 of 3 \\
\hline \multirow{2}{*}{\multicolumn{4}{|c|}{ Dept. : Tool Room }} & & & & & & : & $-08-2003$ \\
\hline & & & & & & & \multicolumn{2}{|c|}{ RE } & : & 01 \\
\hline \multicolumn{4}{|c|}{$\begin{array}{c}\text { Process :- Tool / Mould } \\
\text { Repairing }\end{array}$} & & & & \multicolumn{2}{|c|}{ REV. DATE } & \multicolumn{2}{|c|}{$18 / 01 / 2004$} \\
\hline \multirow{2}{*}{\begin{tabular}{|l|} 
Sr. \\
No.
\end{tabular}} & \multirow{2}{*}{ Aspect } & \multirow{2}{*}{ Impact } & \multirow{2}{*}{\multicolumn{2}{|c|}{$\begin{array}{l}\text { Measur. } \\
\text { Indicator }\end{array}$}} & \multirow{2}{*}{$\begin{array}{c}\text { Present } \\
\text { status }\end{array}$} & \multicolumn{2}{|c|}{ Frequency of } & \multirow{2}{*}{$\begin{array}{l}\text { Present } \\
\text { treatment }\end{array}$} & \multirow{2}{*}{$\begin{array}{l}\text { Type of } \\
\text { control }\end{array}$} & \multirow{2}{*}{$\begin{array}{l}\text { Remarks } \\
\text { reference }\end{array}$} \\
\hline & & & & & & Occur & Meas & & & \\
\hline \multicolumn{11}{|c|}{ NORMAL ASPECTS } \\
\hline 01 & $\begin{array}{c}\text { Noise } \\
\text { generation }\end{array}$ & $\begin{array}{c}\text { Noise } \\
\text { pollution }\end{array}$ & $\mathrm{dE}$ & & 80 & Cont. & $\begin{array}{c}\text { Once in } 6 \\
\text { months }\end{array}$ & Nil & Statutory & \begin{tabular}{|c||}
$\begin{array}{c}\text { Measurement } \\
\text { of noise level } \\
\text { report }\end{array}$ \\
\end{tabular} \\
\hline 02 & $\begin{array}{c}\text { Dust } \\
\text { generation } \\
\text { (By } \\
\text { Grinding) } \\
\end{array}$ & $\begin{array}{c}\text { Air } \\
\text { Pollution }\end{array}$ & \multicolumn{2}{|c|}{$\mathrm{Mg} . / \mathrm{Nm}^{3}$} & Negligible & Cont. & $\begin{array}{c}\text { Not } \\
\text { measured }\end{array}$ & Nil & Nil & Nil \\
\hline 03 & $\begin{array}{l}\text { Heat loss to } \\
\text { atmosphere }\end{array}$ & $\begin{array}{l}\text { Ambient } \\
\text { warming }\end{array}$ & \multicolumn{2}{|c|}{${ }^{\circ}$ Cent. } & \begin{tabular}{|c|} 
Max. $5^{\circ} \mathrm{C}$ \\
above \\
ambient \\
te perature
\end{tabular} & Cont. & $\begin{array}{c}\text { Not } \\
\text { Measured }\end{array}$ & Nil & Nil & Nil \\
\hline 04 & \begin{tabular}{c|} 
Cotton \\
waste \\
generation
\end{tabular} & $\begin{array}{c}\text { Land } \\
\text { Contamination }\end{array}$ & \multicolumn{2}{|c|}{ Kgs } & $\begin{array}{c}\text { Approx. } 60 \\
\text { Kgs/Month }\end{array}$ & Cont. & Monthly & $\begin{array}{c}\text { Disposed to } \\
\text { recyclers }\end{array}$ & Nil & $\begin{array}{l}\text { Monthly issue } \\
\text { from store }\end{array}$ \\
\hline 05 & $\begin{array}{l}\text { Metal } \\
\text { scrap }\end{array}$ & \begin{tabular}{c|c|} 
Land \\
Contamination \\
\end{tabular} & \multicolumn{2}{|c|}{ Kgs. } & \begin{tabular}{|l|} 
Appr $\quad$ x. 30 \\
Kgs/Month \\
\end{tabular} & Cont. & Monthly & \begin{tabular}{|c|}
$\begin{array}{c}\text { Disposed to } \\
\text { recyclers }\end{array}$ \\
\end{tabular} & Nil & Scrap ticket \\
\hline 06 & $\begin{array}{l}\text { Spent } \\
\text { coolant }\end{array}$ & $\begin{array}{c}\text { Water } \\
\text { pollution }\end{array}$ & \multicolumn{2}{|c|}{ Ltrs. } & $\begin{array}{l}\text { Approx. } 30 \\
\text { Ltr./Month }\end{array}$ & Cont. & Monthly & $\begin{array}{l}\text { Effluent } \\
\text { treatment } \\
\text { plant }\end{array}$ & Statutory & \begin{tabular}{|c||} 
Register for \\
spent coolant \\
to powder \\
coating \\
\end{tabular} \\
\hline \multicolumn{11}{|c|}{ ABNORMAL ASPECTS } \\
\hline 07 & Oil leakage & \begin{tabular}{c|c|} 
Land \\
Contamination \\
\end{tabular} & \multicolumn{2}{|c|}{ Ltrs. } & Negligible & Rare & \begin{tabular}{|c|} 
Not \\
Measured
\end{tabular} & \begin{tabular}{|c|} 
Secondary \\
containment
\end{tabular} & Statutory & Nil \\
\hline \multicolumn{11}{|c|}{ EMERGENCY ASPECTS } \\
\hline 08 & Nil & Nil & $\mathrm{Ni}$ & & Nil & Nil & Nil & Nil & Nil & nil \\
\hline \multicolumn{7}{|c|}{ Prepared by: } & \multicolumn{2}{|c|}{ Approved By: } & & \\
\hline
\end{tabular}




\section{References}

[1] Ambika Zutshi and Amrik S. Sohal, (2000), Environmental management systems auditing: auditors' experiences in Australia, Int. J. Environment and Sustainable Development, Vol. 1, No. 1, pp 73-87.

[2] Subhash Babu, A., Madhu, K. and Sahani, N. (1998), Positioning ISO 14000 standards an investigative study covering selected Indian Industries, Proc. ISME Conference, Dec 1998, IIT Delhi, pp 286-291.

[3] Fabio Orecchini, (2000), The ISO 14001 certification of a machine process, Journal of Cleaner Production, Vol. 8, Issue 1, February 2000, pp 61-68.

[4] Martin, R 1998, ISO 14001 Guidance Manual, National Centre for environmental decision-making research: Technical report, viewed 23 August 2010

[5] Company manual. 


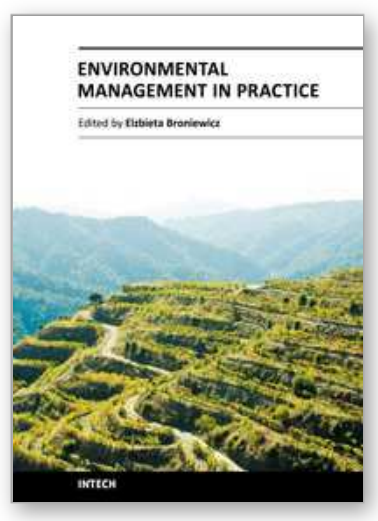

\section{Environmental Management in Practice}

Edited by Dr. Elzbieta Broniewicz

ISBN 978-953-307-358-3

Hard cover, 448 pages

Publisher InTech

Published online 21, June, 2011

Published in print edition June, 2011

In recent years the topic of environmental management has become very common. In sustainable development conditions, central and local governments much more often notice the need of acting in ways that diminish negative impact on environment. Environmental management may take place on many different levels - starting from global level, e.g. climate changes, through national and regional level (environmental policy) and ending on micro level. This publication shows many examples of environmental management. The diversity of presented aspects within environmental management and approaching the subject from the perspective of various countries contributes greatly to the development of environmental management field of research.

\section{How to reference}

In order to correctly reference this scholarly work, feel free to copy and paste the following:

S. B. Jaju (2011). Implementation of ISO 14000 in Luggage Manufacturing Industry: A Case Study, Environmental Management in Practice, Dr. Elzbieta Broniewicz (Ed.), ISBN: 978-953-307-358-3, InTech, Available from: http://www.intechopen.com/books/environmental-management-in-practice/implementation-ofiso-14000-in-luggage-manufacturing-industry-a-case-study

\section{INTECH}

open science | open minds

\section{InTech Europe}

University Campus STeP Ri

Slavka Krautzeka 83/A

51000 Rijeka, Croatia

Phone: +385 (51) 770447

Fax: +385 (51) 686166

www.intechopen.com

\section{InTech China}

Unit 405, Office Block, Hotel Equatorial Shanghai

No.65, Yan An Road (West), Shanghai, 200040, China

中国上海市延安西路65号上海国际贵都大饭店办公楼405单元

Phone: +86-21-62489820

Fax: +86-21-62489821 
(C) 2011 The Author(s). Licensee IntechOpen. This chapter is distributed under the terms of the Creative Commons Attribution-NonCommercialShareAlike-3.0 License, which permits use, distribution and reproduction for non-commercial purposes, provided the original is properly cited and derivative works building on this content are distributed under the same license. 